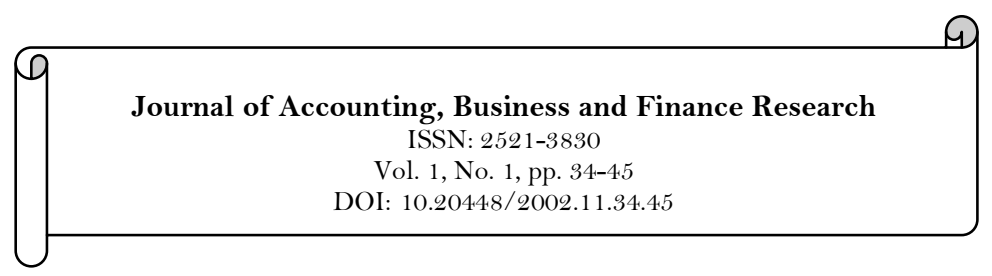

\title{
Interest Rate Spread on Bank Profitability: The Case of Ghanaian Banks
}

\author{
George Owusu-Antwi ${ }^{1}$ \\ Rachna Banerjee ${ }^{2}$ \\ James Antwi ${ }^{3}$ \\ ${ }^{1,2}$ Higher Colleges of Technologies; Dubai Women's College UAE. \\ ${ }^{3}$ University of Delaware USA.
}

\begin{tabular}{|c|c|}
\hline Abstract & \\
\hline $\begin{array}{l}\text { The banking sector in Ghana plays a dominant role in the financial } \\
\text { sector, particularly with respect to mobilization of savings and the } \\
\text { provision of credit. An analysis of bank interest rate spreads is } \\
\text { therefore central to the understanding of the financial intermediation } \\
\text { process and the macroeconomic environment in which banks operate. } \\
\text { This paper is motivated by the fact that although Ghana's financial } \\
\text { sector was liberalized in the early } 1990 \text { s to allow for market } \\
\text { determination of interest rates, concerns about high interest rate } \\
\text { spreads have persisted and attracted a lot of debate in both public and } \\
\text { policy forums. The purpose of the study is to empirically investigate } \\
\text { the interest rate spread on banks profitability in Ghana using } \\
\text { average annual observation data from } 1992-2015 \text { to include } 28 \\
\text { commercial banks. Ordinary least square was used to estimate the } \\
\text { regression coefficients. The empirical results show that bank-specific } \\
\text { factors play a significant role in the determination of interest rate } \\
\text { spreads in the Ghana's banking sector. All the bank specific variables } \\
\text { were found to be significant except Total Assets (TA). Among the } \\
\text { macroeconomic variables, inflation was found to be significant } \\
\text { whereas GDP growth rate was insignificant. The role of the global } \\
\text { financial institutions is changing and so are the banks operating in } \\
\text { Ghana. The banking sector should explore new paths that will } \\
\text { enable them to take advantage of the government's policy of making } \\
\text { the "private sector the engine of growth" to market their products. }\end{array}$ & $\begin{array}{l}\text { Keywords: } \\
\text { Interest rate } \\
\text { Spread } \\
\text { Return on assets } \\
\text { Macroeconomics } \\
\text { Profitability. } \\
\text { Licensed: } \\
\text { This work is licensed under a } \\
\text { Creative Commons Attribution } \\
\text { 4.0 License. } \\
\text { Publisher: } \\
\text { Scientific Publishing Institute }\end{array}$ \\
\hline
\end{tabular}

\section{Introduction}

The interest rate is assumed to be one of the key aspects that shape the profitability of banks and it is a key source of income for commercial banks. The past 12 years have experienced around $45 \%$ of total revenues of Ghanaian banks coming from interest income (Ho \& Saunders, 1981b). Hence, interest rate risk is a major source of risk to which commercial banks are exposed. Insightfully, changes in interest rates can affect a bank's profitability by increasing its cost of funding, reducing returns from assets, and lowering the value of equity (Bawumia, Belnye, \& Ofori, 2005). Moreover, recent decades have ushered in a period of volatile interest rates, confronting the investors with a more unpredictable environment to work on. Consequently, the investor's primary concern is the impact of interest rates on commercial bank revenues, costs and profitability. In a situation where the financial system is not well-developed, inefficient and uncompetitive, banks' lending rates could be artificially high and low deposit rates, with borrowers and savers reducing essentially to "pricetakers" in the markets (Ho \& Saunders, 1981a). In such a case, the market has to accept rates thrown up by an uncompetitive and inefficient banking system. Not surprisingly, banks' lending rates have remained stubbornly high in Ghana, even as the benchmark prime rate has been recently reduced (Bawumia et al., 2005). Several indicators are used to buttress this point. The high level of lending rates or the cost of credit is consistently cited by businessmen to be one of the important disablements to investment, private sector development, and economic growth in Ghana.

The deposit rates, on the other hand, have been persistently pegged low, leaving large spreads between the two rates. Large spreads are usually symptomatic of underdeveloped, inefficient, and uncompetitive financial systems. According to Bawumia et al. (2005) interest rate spreads within the Ghanaian banking 
industry are among the highest in Africa. He considers this to be associated with the liberalization of interest rate through financial sector reforms which has been characterized by high implicit costs with tight monetary policy achieving through increased reserves and cash ratio. Banks have tried to justify these spreads in terms of their "high cost of funds" and "lending risks." Among the costs cited by the banks are operational costs, costs associated with macroeconomic instability, and costs related to the unremunerated cash reserve requirement imposed by the monetary authorities (Bawumia et al., 2005).

High interest rates reduce the incentive to invest and thereby slow down not only industrial growth but also economic growth. Indeed, Ghana's relatively high interest rates and high cost of credit make the country less competitive in attracting investments, which impedes growth. High cost of credit ranks among the top concerns often cited by investors as impeding business in Ghana. If interest rates, and the cost of credit, are brought down significantly, Ghana would be able to attract higher levels of investments which would add several notches to its growth rate (Amuakwa-Mensah \& Marbuah, 2015). By increasing the cost of credit and production, high interest rates also result in high prices of goods and services that consumers have to pay. The highest level of Ghana's interest rates has continued to be a source of concern in the country. Even as some measure of macroeconomic stability has been achieved historically as well as in the recent past; interest rates have generally remained stubbornly high (Bawumia et al., 2005).

The importance of the subject and the need to fill an obvious public information gap has motivated this study. In Ghana, the banking sector plays a dominant role in the financial sector, particularly with respect to mobilization of savings and the provision of credit. In the light of this, an analysis of bank interest rate spreads is therefore central to the understanding of the financial intermediation process and the macroeconomic environment in which banks operate. This paper is motivated by the fact that although Ghana's financial sector was liberalized in the early 1990s to allow for market determination of interest rates, concerns about high interest rate spreads have persisted and attracted a lot of debate in both public and policy forums. However, there has been little empirical research on this issue, particularly with respect to the analysis of interest rate spreads at the micro level or bank level.

The purpose of this paper is to empirically investigate the interest rate spread on banks profitability in Ghana using unbalanced panel data from 1992 to 2015 which includes 28 commercial banks. In this sphere, both banks-specific and macroeconomic factors are considered. The study contributes to the literature both by extending the analysis of interest rate spread and banks in Ghana. Specifically, the study seeks to analyze the factors which affect interest rate changes by applying econometric analysis to estimate the model. Despite a growing body of literature on interest rate spread on banks profitability, a few studies have investigated the explanatory factors behind the interest rate spreads indicator.

The remainder of the study is as follows: Section 2 describe the overview of the Ghana's banking system and the trends. Section 3 includes the literature that reviews the various studies on interest rate changes and the bank's performance. Attention is focused on the empirical studies of bank interest rate changes and trends in the banking system. Section 4 identifies the data source and develops the model to assess the interest rate changes. Section 5 presents empirical results and interpretations. The final section is devoted to the summary and conclusion.

\section{Overview of Ghana's Banking System}

In Ghana, the banking sector has traditionally been segmented into a merchant, commercial (retail) and development banks. While merchant banks have been restricted to corporate clients, the commercial and development banks have traditionally had customers across the entire financial system. It is against this backdrop and the need to create a level playing field for all banks that the idea of Universal Banking (Bank of Ghana, 2004) was adopted. The aim is to allow all banks that comply with the prescribed capital requirements, the freedom to engage in permissible banking business without restrictions and thereby eliminate the compartmentalization. Hinson (2004) has noted that "before the passage of the Universal Banking Law, banking was conducted along such narrow scopes as commercial, developmental or merchant banking. However, with the passage of the Universal Banking Law however, all types of banking can now be conducted under a single corporate banking entity and this has greatly reorganizes the competitive scopes of several banking products in Ghana. The banking system in Ghana consists of a national network of licensed and statutory financial institutions engaged in the business of banking under the banking laws of Ghana. Bank of Ghana is the central bank and it regulates the activities of all the banks. The banking sector over the last decade has seen appreciable growth and improvements in performance as a result of reforms instituted by governments before this period (Bank of Ghana, 2011). Some of the reforms implemented include the Financial Sector Adjustment Program (FINSAP II and I), Non-Performing Assets Recovery Trust (NPART) and the Foreign Exchange Bureau legislation. A new Banking Law was also promulgated. The Bank of Ghana was strengthened to enhance its capacity to play its regulatory role. From independence in 1983, there were twelve (12) banks (Bank of Ghana, 2004). Over the last decade (1993-2003) and beyond, eleven (11) new banks have been incorporated. Some significant events have occurred during this period such as mergers (SG-SSB, and National Savings and Credit Bank), liquidation (BHC, Co-op), privatization of state owned banks and change of ownership (GCB, SSB, NIB) (Bank of Ghana, 2007). Competition in the banking sector has escalated over 
the period. Commercial and development banks have gone beyond their limit and have ventured into international trade financing, commerce and corporate lending, treasury services payment financing, syndication, etc., which used to be the preserve of merchant banks. Some significant events have occurred during this period such as mergers (SG-SSB, and National Savings and Credit Bank), liquidation (BHC, Co$\mathrm{op}$ ), privatization of state owned banks and change of ownership (GCB, SSB, NIB). Competition in the banking sector has escalated over the period. Commercial and development banks have gone beyond their limit and have ventured into international trade financing, commerce and corporate lending, treasury services payment financing, syndication, etc., which used to be the preserve of merchant banks (Bank of Ghana, 2004).

\subsection{Trends in Ghana's Banking}

The Ghana banking system has changed dramatically. The reports by Bank of Ghana (2011) indicates that, the industry has remained profitable, liquid and solvent. The number of deposit money Banks (DMBs), non-bank financial institutions (NBFTs) and the number of Rural and community Banks (RCBs) have remained at 27, 29 and 135 respectively (Obuobi, 2012). In 2012, the financial sector also experienced some changes in the competitive environment. This is evident from the market shares of selected banks see Table 1. This was mainly due to mergers and acquisitions in the banking industry during the year. Access bank Ghana with a market share of $1.20 \%$ acquired International bank of Ghana, which had a market share of $3.20 \%$. Ecobank Ghana with a market share of $9.00 \%$ acquired the Trust bank Limited, which had a market share of $2.80 \%$.

Table-1. Market Shares of Selected Banks in 2012

\begin{tabular}{c|c}
\hline Banks & Market Share \\
\hline GCB & $12.60 \%$ \\
\hline BBGL & $9.80 \%$ \\
\hline SCB & $10.00 \%$ \\
\hline EBG & $11.80 \%$ \\
\hline ADB & $6.00 \%$ \\
\hline STANBIC & $5.30 \%$ \\
\hline MBG & $4.80 \%$ \\
\hline SG-SSB & $4.10 \%$ \\
\hline CED & $3.00 \%$ \\
\hline SELLITY & $3.90 \%$ \\
\hline
\end{tabular}

The banking industry remained profitable with increases in some profitability indicators, and decreases in others see Table 2 . These changes were attributed to the reduction in interest earnings due to the downward trend in lending rates (Bank of Ghana, 2011).

Table-2. Trend in selected profitability indicators of the banking industry from $2008-2011$

\begin{tabular}{l|l|l|l|l}
\hline INDICATORS & $\mathbf{2 0 0 8}$ & $\mathbf{2 0 0 9}$ & $\mathbf{2 0 1 0}$ & $\mathbf{2 0 1 1}$ \\
\hline ROA & 3.2 & 2.8 & 3.8 & 3.9 \\
\hline ROEA & 4.3 & 3.8 & 5.1 & 5.3 \\
\hline ROE & 23.7 & 17.5 & 20.4 & 19.7 \\
\hline NIS & 8.6 & 9.1 & 11.1 & 9.7 \\
\hline CIR & 64.8 & 62.8 & 58.5 & 59.8 \\
\hline NIM & 10.1 & 10.8 & 12.4 & 10.2 \\
\hline ROA & 2008 & 2009 & 2010 & 2011 \\
\hline
\end{tabular}

Sources: Adapted from Obuobi (2012)

The Bank of Ghana reported a $28.8 \%$ increase in the total assets of banks and NBFIs over the 2011 fiscal year. The increase in total assets was the results of a $22.5 \%$ increase in loans and advances a $36.9 \%$ increase in investment balances, and $37.2 \%$ increase in cash and bank balances. This increase in assets is also explained by the $36.7 \%$ increase in deposits. The increase in deposits is due to the upward trend in national savings from 2009 to 2011.

The most important factors driving changes in the industry include advances in information technology (IT), the deregulation of financial services at the national and regional level, and the effects of the globalization process. The application of technological innovation to the banking has led to the introduction of additional delivery channels such as electronic banking (internet), debit and credit cards, and automated teller machines (ATM) among others.

A combination of macroeconomic pressures, IT developments, global markets and banking crises forced the industry regulators to deregulate the Ghanaian markets which open-up the playing field for foreign competitors and additional local entrants. With further changes made in the industry in recent years, there has 
been an emergence of private banks, non-bank financial institution such as the new microfinance office, mergers and acquisitions, and the entrance of multinational foreign banks (Obuobi, 2012).

Today the banking industry is fairly saturated with competition from local banks and multinational foreign banks. This competition has been noted for playing role in the increased quality of corporate governance. In the battle for market share, banks are now forced to maximize on efficiency, profitability, and market share. The effects of these factors are evident in the recent mergers and acquisition of the intercontinental Bank of Ghana and the Trust Bank Limited. Global multinational like Barclays Bank, Citigroup, Societe Generale and Standard Chartered Bank are placing intense competitive pressure on Ghana's local banks. This has opened the door for the introduction of a wide variety of business and consumer banking products and services. The greater demand for shareholder value has increased competitive pressure to maximize returns on assets (Obuobi, 2012)(Bank of Ghana, 2011). Many banks have attempted to achieve this by cutting operational costs. However, in the long-term, the best approach must be to ensure that a company's products and services are best aligned with the needs of consumers. This will generate greater revenue, consumer loyalty and long-term profitability (Bokhari, 2004; Obuobi, 2012)(Bank of Ghana, 2011).

It is estimated that Africa already has as many middle-income class consumers as China or India. The African Development Bank suggested that about 34\% of Africans could be classified as middle-income consumers (Obuobi, 2012). This was based on a figure of 313 million middle-income class consumers a significant increase from the reported 180 million middle-income consumers in 1980. A representative from Procter \& Gamble estimated that about $20 \%$ to $25 \%$ of households in sub-Saharan Africa have enough discretionary income to spend on consumer goods. This figure was projected to increase to $50 \%$ by 2020 (Obuobi, 2012). In July 2011, the World Bank recognized Ghana as a country with middle-income status based on its country classifications. With the growth in the population of middle-income Ghanaians, some important changes of the competitive market will include an increased demand for e-banking increased pressure for the cost reduction of services, better delivery of products and services and a greater need for engaging marketing initiatives.

\section{Empirical Literature}

Despite the widespread implementation of costly financial sector reform programs in the developing world, banking sectors in many developing countries are still characterized by persistently high interest rate spreads. This is indicative of inefficiency in the banking sectors of developing countries, as it is now widely acknowledged that interest rate spreads are an adequate measure of bank intermediation efficiency (Sologoub, 2006). It is argued that a more efficient banking system benefits the real economy by allowing "higher expected returns for savers with a financial surplus, and lower borrowing costs for investing in new projects that need external finance (Quaden, 2004). Therefore, if the banking sector's interest rate spread is large it discourages potential savers due to low returns on deposits and thus limits financing for potential borrowers. Chirwa and Mlachila (2004) concur and assert that macroeconomic instability and the policy environment have important impacts on the pricing behavior of commercial banks. They noted that the macroeconomic variables typically thought to be determinants of interest rate spreads include inflation, growth of output, and money market real interest rates. Using quarterly data spanning from 1996 to 2010, Eita (2012) found macroeconomics variables as an important factors explaining interest rate spread in Namibia. His results registered inflation rate, bank rate and the treasury bills rate increase and financial deepening to be associated with the decrease in interest rate spread.

Tarus, Chekol, and Mutwol (2012) used pooled and fixed effects regression approached to examine the determinants of net interest margin of commercial banks in Kenya. Their results designated operating expenses and credit risk to have a positive effect on net interest margin. Their study has also divulged higher inflation to be associated with widen net interest margin whereas economic advancement and market intensity have adverse consequences on net interest margin. Garr and Kyereboah-Coleman (2013) employed unbalanced panel data from 33 commercial banks covering the 21-year period from 1990 to 2010 to examined bank and industry specific as well as macroeconomic variables impact on interest rate spreads in commercial Banks operating in the Ghanaian economy. Their results proposed that interest rate spread in Ghana is significantly influenced by bank- specific and macroeconomic variables. Using firm and market specific factors, Bawumia et al. (2005) reveal that factors including lending risk, public sector borrowing, low savings rates, inflation and exchange rates play critical roles in the systemic rise of interest rate spread in Ghana. Asamoah and Adu (2016) confirm the connection between inflation and interest rates and other macroeconomic determinants in Ghana using data from 1960 to 2009. They concluded that the positive inflation-interest rate connection is due to the short-term interest rate as a principal policy commentator in the inflation targeting framework of the central bank. The study by Sheriff and Amoako (2014) confirms the fundamental macroeconomic indicators such as inflation and fiscal deficit to have contributed to the high interest rate spread in Ghana. Kader and Leong (2009) conducted their study to determine the impact of interest rate changes on the demand for Islamic financing in a dual banking system. They described the different changes in the interest rate that attached by the profit motive to substitute Islamic financing for conventional bank loans and vice versa. Interest margins are therefore an important component of banks' profitability as well as an indicator of the 
efficiency of a country financial system. On the other hand, large spreads could hamper the growth of savings and investment and imply that the cost of using the financial system may become exorbitant for certain borrowers. In addition, high interest rate margin can have major implications for financial intermediation as they can increase the cost of capital, which in turn limits the financial resources available to potential borrowers, thereby reducing the volume of investment opportunities and/or limiting them to sub-optimal level (Winston \& Roland, 2002).

Gambacorta (2004) studied the factors explaining cross-sectional differences in bank interest rates of Italian banks by considering both micro and macroeconomic factors. His results showed that interest rates on short term lending of liquid and well capitalized banks react less to monetary policy shocks. Bank size was found to be irrelevant in influencing interest rate margins. Demirguc-Kunt and Huizinga (1999) examines interest spreads in a cross-country set up using data covering commercial banks from 80 countries across the world. The study found that differences in interest margins and bank profitability are explained by several factors such as bank characteristics, macroeconomic variables, explicit and implicit bank taxation and deposit insurance regulation. Folawewo and Tennant (2008) studied the determinants of interest rate spread in 33 Sub Saharan African (SSA) countries focusing on macroeconomic variables. Their results show that interest rate spread is influenced by the extent of the crowding out effect of government borrowing, public sector deficits, discount rate, inflation, level of money supply, reserve requirement, level of economic development and population size.

According to Gambacorta (2004) lending rates have a positive relationship with real GDP and inflation. An increase in real economic activity makes projects that would otherwise appear unfeasible become profitable when discounted to the present. The increase in economic activity therefore increases demand for credit. An increase in real GDP and inflation are negatively related with deposit rates. When the economy is booming, it pushes up demand for deposits and therefore banks have no incentive to increase deposit rates.

Siddiqui (2012) estimates the interest rate spread in Pakistan based on individual bank specific factors using annual panel data of 22 banks. The spread was found to be significantly affected by administrative costs, non-performing loans and return on assets in all the regressions (pooled, fixed and random effects regressions). A more recent study on determinants of bank interest margins in Sub-Sahara Africa (SSA) has been done by Ahokpossi (2013) using a sample of 456 banks in 41 SSA countries. The results show that bankspecific factors such as credit risk, liquidity risk and bank equity are important, determinants of interest margins, but such spreads are not sensitive to economic growth. Peshev (2015) analyze the factors affecting the interest rate spreads of commercial banks in Bulgaria. Using the Engle-Granger two-step method (1987) and the bounds testing approach of Pesaran, Shin, and Smith (2001). His findings of the study is that the interest rate spreads dynamics in Bulgaria in the period of Q1.2004 - Q3.2014 was under the long-term influence of factors such as: economic activity, market concentration, foreign ownership, external liabilities, profit margins, loan to asset ratio, loan to deposit ratio, house prices, inflation, interbank lending rates and stock prices.

Grenade (2007) estimates the determinants of commercial banks interest rate spreads in the Eastern Caribbean Currency Union using annual panel data of commercial banks. The spread was found to increase with an increase in market power, the regulated savings deposit rate, real GDP growth, reserve requirements, provision for loan losses and operating costs. Aboagye, Akoena, Antwi-Asare, and Gockel (2008) studied the response of net interest margin of banks to changes in factors that are bank-specific, banking industry specific and Ghanaian economy macroeconomic factors. It was found that an increase in the following factors increases the net interest margin of banks: bank market power (or concentration), bank size, staff costs, administrative costs, extent to which a bank is risk averse and inflation.

Nampewo (2013) studied the determinants of the interest rate spread of the banking sector in Uganda using time series data for the period 1995 - 2010. The study applies the Engle and Granger two-step procedure to test for co-integration between the bank rate, Treasury bill rate, exchange rate volatilities, the ratio of money supply to gross domestic product (M2/GDP) and the proportion of non-performing loans to total private sector credit. The results show that the interest rate spread in Uganda is positively affected by the bank rate, the Treasury bill rate and non-performing loans. M2/GDP ratio and real GDP on the other hand, have a negative influence on the spread.

The economy school of thought requires banks to hold a certain fraction of their demand deposits as either vault cash or deposits with the central bank. The purpose is to reduce the risk of bank run. A study by Ngugi (2001) indicated that the widened interest rate spread in Kenya was the result of tightening monetary policy and increasingly treasury bills rate. This was consistent with a study by Crowley (2007) who found higher reserve requirements to be associated with higher interest rate spreads in English-speaking African countries. Chirwa and Mlachila (2004) used a panel data to ascertain the drivers of the interest rate spread in Malawi's commercial banking sector particularly during the period of liberalization i.e. the 1990s. Their results indicates increased in reserve requirements and inflation to be the main drivers of wide interest rate spread in Malawi's banking system. Gelos (2006) in Latin America found high interest rates and reserve requirements to be the major donors to high interest rate spreads, while GDP growth was associated with narrower interest rate spreads. Kwakye (2010) and Sarpong, Winful, and Ntiamoah (2011) also confirm that 
in Ghana, commercial banks respond to increases in reserve requirements by increasing the margin between lending and deposit rates. Sarpong, Winful, and Ntiamoah (2013) investigated the causal factors behind the increase spread in interest margins in the Ghanaian economy. Their study relied on time series data and the analysis was based on panel EGLS. The authors revealed that the commercially banks do not only use high interest spread to cushion against their operational costs and the legally mandatory reserve required by the central bank but also indicates that banks with market power leverage on this to their advantage whiles others use it to indicate their loan quality. Furthermore, the banking industry concentration, economic activity proxies with GDP, inflationary pressures and the rates on Treasury bill did not have any influential power on interest rate spread as indicated by previous studies.

\section{Methodology \\ 4.1. Data Consideration and Sources}

This study uses income statement and balance sheet data of commercial banks from the annual report of the Bank of Ghana. The macroeconomic data are obtained from the International Financial Statistics Yearbook. The study is conducted using average annual observation data and covers the period from 19922015. Sarpong et al. (2011) used time series and the cross section dimensions data to understand bank interest spread.

\subsection{Description and Explanation of Variables}

This study posed one dependent variable. Since banks deals with a lot of interest rate, this study uses bank interest rate spread (IRS) as a proxy to generalized interest rate effect on bank performance. The bank interest rate spread is defined as the difference between bank lending and deposit rates. According to Sologoub (2006) bank interest rate spread should be measured as the difference between the average interest rate earned on loans and the average interest rate paid on deposits for individual commercial banks. However, due to the unavailability of such bank-level data on interest rates, and to better understand the broad state of efficiency of financial intermediation in an economy, banking sector spreads are examined instead. In this regard, the interest rate spread can be redefined as the ratio of net interest income (banks' interest income - banks interest expenses) to total assets. This mark-up reflects the bank's interest profitability that covers the cost of intermediation which, according to the industrial organization point of view, is the difference between the price of bank intermediation and the cost of its output. In fact, this margin should reflect a bank specific component, an information premium for assessing and monitoring investments, market structure and a premium for managing risks (Sologoub, 2006).

The study used six independent variables. These are: return on asset (ROA); net interest income (NII); operating cost (OPC); total asset (TA) uses as a proxy to bank size, inflation (INFL) and GDP growth (GDPG). ROA is computed as net income divided by average total assets. This is generally considered as a good indicator to evaluate the profitability of the assets of a firm in comparison to other firms in the same industry. A positive relationship with interest rate spreads is hypothesized. Raharjo, Hakim, and Maulana (2014) measured bank profitability through return on assets ratio and achieve a positive association with net interest margins. Banks in Ghana traditionally rely on interest income from loans and advances relative to non-interest income assets are likely to be associated with higher spreads since they may not be willing to forego interest income traditionally generated from higher spreads. To this effect net interest income (NII) is incorporated in the model.

According to Gelos (2006) banks incur costs of financial intermediation such as screening loan applicants to assess the risk profile of borrowers and monitor the projects for which loans are advanced. An increase in operating costs is expected to have a positive influence on interest rate spreads. High operating costs are likely to include costs due to inefficiency leading to higher spreads and hence this variable is commonly used as an indicator of operational inefficiency. A higher cost of financial intermediation will drive up interest rates on loans while depressing interest rates on deposits. In the light of this, Operating cost (OPC) is infused in the regression model and is computed as operating costs as a ratio of total net operating income. Chirwa and Mlachila (2004) incorporated operating cost in his regression model and found a positive relationship with interest rate spread. Ideally one would expect bigger banks to be associated with lower interest rate spreads, arguably because of large economies of scale and the ability to invest in technology that would enhance efficiency. However, to the extent that bank size connotes control of the market in the deposit and loan markets, a positive relationship between interest rate spreads and bank size should not be surprising. Bank size is measured as the log of total bank's assets. In this study total asset (TA) is used as a proxy to bank size.

Ahokpossi (2013) found a positive relationship macroeconomic factors also explain variation in interest margins. Inflation is associated with higher realized interest margins and higher profitability. Inflation entails higher costs - more transactions, and generally more extensive branch networks - and also higher income from the bank float. A positive relationship between inflation and bank profitability would imply that bank income increases more with inflation than bank costs. Further, high real interest rates are associated with higher interest margins and profitability, especially in developing countries. This may reflect that in developing countries demand deposits frequently pay zero or below market interest rates. Inflation and bank 
spreads are thought to be related to relative price changes. Thereby, if inflation is not anticipated, bank assessments may not be truthful and may yield high liquidity, and credit risk. An increase in inflation deteriorates the net present value of future cash flows and therefore erodes the real value of money reserves and ultimately increases the solvency risk of banks. With this in perspective, inflation rate (INFL) is incorporated in the model. The study expects inflation to be positively related to interest rates. Asamoah and Adu (2016) also found inflation to be negatively related to interest rate spread in the short run. Peshev (2015) however employed inflation in his Engle-Granger two-step method and found inflation to be positively related to interest rate spread in the long-run. The macroeconomic environment might influence the behavior of bank margins. An adverse macroeconomic condition may deteriorate banks' performance by raising the volume of non-performing loans in the economy. Therefore, the study expects a positive relationship between the general economic activity measured by the real growth (GDPG) and bank performance as debt-servicing capacity of domestic borrowers may weaken as a result of a slowdown of economic activity. Garr and Kyereboah-Coleman (2013) employed GDP growth in their model and found a positive relationship with interest rate spread.

\subsection{Model and Specification}

This section of the paper provides the theoretical basis of interest rate margin or spread. Interest rates are the centrepiece of commercial banks' core business of financial intermediation. They are the key price in the financial sector, the main transmission mechanism of monetary policy, the main vehicle for matching supply and demand and, normally, the key determinant of profitability. Their level reflects banks' perception of risk (country and creditor), market liquidity conditions, and the depth of financial markets-which affects banks' ability to spread their risk, the cost of doing business, and the level of competition in the financial sector.

Net interest income is a fundamental part of banking. Banks collect deposits in return for paying a certain rate of interest, and they use the deposits to make loans at a higher rate. The spread between those two rates — the net interest margin - fluctuates for a number of reasons, most of which are out of banks' control. A key factor is the external interest-rate environment. A steep yield curve, on which long-term rates are much higher than short-term ones - as can happen when the Central bank drives down short-term rates with an easy money policy — tends to increase net interest income, whereas a flat one does the opposite. Changes in net interest income can significantly mask the underlying strength (or weakness) of a bank's business, in some cases for years. Indeed, in the recent past a full range of banking "experts" have greatly underestimated the negative impact of falling net interest income (and thus greatly overestimated banks' earning power) as the interest-rate environment became unfavorable, leading to earnings shortfalls and highlighting poor capital allocation (Ho \& Saunders, 1981b).

Two modelling frameworks have been used to study the determinants of bank interest margins. The dealership approach, which views banks at risk-adverse dealers in the loan and deposit markets Bank interest margins are shown to be fees charged by banks for the provision of liquidity. The micro-model of the banking firm, on the other hand, views the banking firm in a static setting where demands and supplies of deposits and loans simultaneously clear both markets (Ho \& Saunders, 1981a). These models predict that market structure, operating costs, bank risk aversion, money market interest rates volatility, credit risk, the covariance between interest rate risk and credit risk, average size of the credit and deposit operations and equity capital influence the determination of bank spreads. However, practical investigations have shown that other elements such as regulation financial system development and macroeconomic factors may alter the bank interest spreads.

The hypotheses with respect to the likelihood that interest rate spread will affect bank's profitability are tested using the following model in Equations 1. With this model, interest rate spread impact on Ghana's bank performance is estimated. Previous studies have estimated the model in log-linear form. This study also estimated the model in log-linear form. This is to facilitate the ease of calculating the elasticity (interest rate changes), which is used to measure the level of banks profitability. The full model used for testing interest rate spread on banks profitability is as follows:

$\ln (\mathrm{IRS})=\mathrm{Q}+\beta_{1} \ln \left(\mathrm{ROA}_{\mathrm{it}}\right)+\beta_{2} \ln \left(\mathrm{NII}_{\mathrm{it}}\right)+\beta_{3}\left(\mathrm{OPC}_{\mathrm{it}}\right)+\beta_{4}\left(\mathrm{TA}_{\mathrm{it}}\right)+\beta_{5} \ln \left(\mathrm{INFL}_{\mathrm{it}}+\beta_{6} \ln \left(\mathrm{GDPG}_{\mathrm{it}}\right)+\mathcal{E}(1)\right.$

Where:

IRS = interest rate spread

$\mathrm{ROA}=$ return on asset

$\mathrm{NII}=$ net interest income

$\mathrm{OPC}=$ operating cost

TA = total asset (proxy for size)

$\mathrm{INFL}=$ rate of inflation

GDPG $=$ gross domestic product growth rate

$\varepsilon=$ error term

$\ln =$ natural $\log$

In the above model the dependent variable is given as interest rate spread. The explanatory variables are return on asset, net interest income, operating cost, total asset. The macroeconomic variables; inflation and 
gross domestic product growth are use as control variables. The general economic development, macroeconomic stability, and institutional framework are controlled, since they are expected to affect the banking system performance. Demirguc-Kunt and Huizinga (1999) found that the banking system structure indicators have a less-close relationship with competitiveness indicators in more developed countries than in less developed countries. Claessens and Laevan (2004) found per-capita GDP and inflation to be insignificant.

\section{Results and Interpretation of the IRS Model}

Before presenting the results of the IRS model of Equation 1, we first presents the descriptive statistics depicted on Table 3.

\subsection{Descriptive Statistics for the Dependent and Independent Variables}

Table 3 shows the mean values and the standard deviations of the variables understudy. The mean value and the standard deviation for the dependent variables, interest rate spread (IRS), and return on asset (ROA) remains fairly stable throughout the sample period. It should be pointed out that the mean values for the net interest income (NII) and operating cost (OPC), are relatively low (10.29 and 1.72, respectively, in million dollars), which seemingly divulges that their sample is biased toward large banks on the average terms. These variables exhibit low standard deviation units around the mean. The mean value for GDP growth (GDPG) and inflation (INFL) which are used as a measure to economic development, exhibits a fairly high minimum value and a high standard of deviation units around the mean.

To determine the probable strength of relationships between different pairs of dependent and independent variables, a standard correlation matrix is used. It is however, assumed that for an acceptable correlation coefficient, the p-value for accepting the null hypothesis should be less than $5 \%$.

Table-3. Descriptive Statistics for the period 2000-2012.

\begin{tabular}{|c|c|c|c|}
\hline VARIABLES & MEAN & MED & STANDARD. DEVIATION \\
\hline IRS & 11.31 & 9.69 & 6.77 \\
\hline $\mathrm{ROA}$ & 6.63 & 6.80 & 0.97 \\
\hline NII & 10.29 & 7.72 & 7.71 \\
\hline $\mathrm{OPC}$ & 1.72 & 1.43 & 2.44 \\
\hline TA & 14.23 & 9.37 & 18.72 \\
\hline INFL & 16.19 & 11.17 & 20.17 \\
\hline GDPG & 49.30 & 52.9 & 14.77 \\
\hline
\end{tabular}

Notes: IRS denotes interest rate spread; ROA is net income to total asset; NII denotes net interest income; OPC represents operating cost; TA represents total asset used as a proxy to size; INFL and GDPG (inflation and gross domestic product growth respectively) used as a macro-economic indicators.

The statistical significance of a correlation coefficient is a function of the magnitude of the correlation and the sample size. With a large number of data points, even a small correlation coefficient can be significant. It is important to remember that correlation indicates only the strength of a relationship; however, it does not imply causality (Johnson, Johnson, \& Buse, 1987). These initial and elemental relationships help the process of selecting repressors and researching their potential impact on the explained variable and their significance. Although these individual relationships are not indicative for the causation, the sign and the value of the individual coefficient and for its significance, being part of a regression based on multiple repressor, they are supposed to give cursory relation expectations. Table 4 presents the correlation matrix of all the variables involved in the empirical analysis.

As expected, the dependent variable exhibits a weak correlation with the explanatory variables. Noticeably, low values are reported for ROA; NII; OPC; TA; INFL and GDPG. These figures suggest the possibility of finding close-to-zero and non-significant elasticities in the next step of the analysis, which is devoted to the estimation of the econometric model presented above. Base on the results of the correlation matrix we affirm that autocorrelation and multicollinearity is not an issue.

Table-4. Correlation Matrix of the Variables.

\begin{tabular}{l|l|l|l|l|l|l}
\hline & ROA & NII & OPC & TA & INFL & GDPG \\
\hline ROA & 1 & 0.532 & 0.085 & 0.073 & 0.067 & 0.078 \\
\hline NII & 0.532 & 1 & -0.527 & 0.083 & -0.554 & -0.688 \\
\hline OPC & 0.085 & -0.527 & 1 & 0.089 & 0.096 & 0.099 \\
\hline TA & 0.073 & 0.083 & 0.089 & 1 & 0.089 & 0.090 \\
\hline INFL & 0.067 & -0.554 & 0.096 & 0.089 & 1 & 0.097 \\
\hline GDPG & 0.078 & 0.688 & 0.688 & 0.099 & 0.097 & 1 \\
\hline
\end{tabular}

Sources: Authors calculation. ROA denotes return on asset; NII is net interest income; OPC Denotes operating cost; TA denotes total asset a proxy for bank size; INFL represents inflation rate GDPG denotes gross domestic product growth. 
Table 5 presents the results of the regression model (1). The empirical results shows that bank-specific factors play a significant role in the determination of interest rate spreads in Ghana's banking sector see Table 5. All the coefficients for bank specific variables have the expected signs and are highly statistically significant at one percent in all the estimated equation except operating cost ratio which is significant at the five percent significance level. The fundamental regression statistics shows that $\mathrm{R}^{2}(53.3 \%)$ is relatively high implying that overall goodness of fit of the model is satisfactory. It also means that about $53.3 \%$ of IRS variation is explained by the model. Further, the Durbin Watson Statistic (1.78) shows that there is no autocorrelation in the residuals. The F-test was used to determine whether the regression equation explained a significantly greater amount of the interest rate spread than would be accounted for by random chance. The F-statistic of 27.43 suggests that the six independent variables jointly impact IRS. The t-tests were used to determine the significance of the explanatory variables.

The return on assets ratio leads to smaller values for the dependent variable, in contrast to the long-term results. It can be assumed that lower profitability margins motivate banks to widen the lending spread, thus achieving better income results in the future and offsetting lower returns in the past. Higher return ratios, however, lead to lower interest rate spreads in the near term, with banks aiming to expand credit and deposit activity at the expense of lower lending margins, probably targeting bigger market share.

Table-5. Regression results for IRS model.

\begin{tabular}{l|l|l|l}
\hline IRS MODEL & COEFFICIENTS & (STD.ERROR) & T-STATISTICS (PROB) \\
\hline INTERCEPT & 2.491 & $(0.420)$ & $4.333^{*}$ \\
\hline ROA & 0.443 & $(0.163)$ & $1.744^{*} *$ \\
\hline NII & -0.047 & $(0.017)$ & $-2.925^{*}$ \\
\hline OPC & -0.073 & $(0.003)$ & $-3.062^{*}$ \\
\hline TA & 0.654 & $(0.400)$ & 1.094 \\
\hline INFL & -0.043 & $(0.015)$ & $-2.407^{*}$ \\
\hline GDPG & -0.013 & $(0.018)$ & -0.988 \\
\hline R $^{2}$ & 2.491 & $(0.420)$ & $4.333^{*}$ \\
\hline DW Statistics & 0.443 & $(0.163)$ & $1.744^{*}$ \\
\hline
\end{tabular}

The results of the study shows a positive relationship between return on assets and interest rate spreads. The ROA coefficient indicates (.443) at .10 significance level. The positive effect could be interpreted as an indication of profit-maximizing behavior whereby banks with higher profitability relative to average assets are also inclined to charge higher borrowing rates relative to the deposit rates. A study by Siddiqui (2012) found a positive effect of return on assets on interest spreads. Similar results were found by Ahokpossi (2013) in his study on determinants of interest rates spread. He concluded that return on average assets plays a key role in interest rates determination. However, the result contradicts Europeans banks findings by Mercieca, Schaeck, and Wolfe (2007) where inverse relationship was found between interest rate spread and profitability. Other bank-level variation that more positively determines the interest rate spreads are, net interest income as a ratio of total income and the extent of operating cost. The higher the bank's income share derived from interest income, the higher the spreads. The coefficient for NII is indicated by (-0.47). Interest rate spread of Ghanaian deposit's banks is positively related to the operating costs variable, the coefficient is significant at the $5 \%$ level. Therefore banks that incur high operating expenses operate with wider margins to compensate their high intermediation costs. This coefficient (OPC) exerts the lowest impact on bank spread; a -0.073 standard variation of operating costs spurs a $5 \%$ change in standard deviation of bank spread. In other words, a reduction of about a seventh a percentage point in operating costs reduces the bank margins by a tenth a percentage. This finding is similar to those of Maudos and de Guevara (2004).

There is a positive relationship between bank size (TA) and interest rate spreads, further confirming the positive relationship observed under the exploratory analysis — that is, the bigger the bank size, the higher the spread. However, size (TA) seems to be insignificant implying that this factor do not affect bank margins directly. Ultimately, the increase in activity volume does not seem to influence the default risk and bank managers might be lacking the power to act directly on the bank spread. The regression coefficient is given by (0.654). Improving economic activity enhances banks' confidence in the economy and tends to stimulate lending at the expense of lower lending rates and lending spreads. However, in the results of Mihailov (2014), a positive relationship between the business climate and the lending spreads is found, despite the prevailing hypothesis that banks tend to decrease lending spreads as the economic conditions improve. The positive relationship can be explained with the higher/lower required returns associated with improving/deteriorating economic conjuncture. A rise in economic performance as captured by GDP growth rate has the effect of lowering the spreads but it is not statistically significant in our equation. The regression coefficient for GDP growth is given by -0.013. It can be assumed that current GDP growth rate do not stimulates banks in requiring larger interest rate spreads, either because banks expect the situation to change for worse, i.e. being rational, or because banks require higher returns as economic conditions improve. Inflation effect is also found 
to be statistically significant with the coefficient of 0.043. These results are consistent with those of other studies based on African countries. Ahokpossi (2013) using a sample of banks in SSA countries found an insignificant impact of economic growth on the level of different measures of spreads. The macro country characteristics, inflation (INFL) do appear to influence bank spread and inflation shocks do not seem to be passed equally through the lending and deposit rates. This result do not confirms those of Naceur (2003) that inflation and real output growth influence neither bank margins nor bank profitability of deposit institutions in Tunisia. The findings of this study is also similar to those of Were and Wambua (2014) who revealed that inflation rate highly influences interest rates spread. Tarus et al. (2012) in his study on determinants of interest rates found out that one of the key determinants of interest rates spread was inflation rate and other macroeconomic factors. His findings were similar to those obtained from this study. The results of this study is also consistent with the results obtained by Njeri, Ombui, and Kagiri (2015) who found interest rate spread to be influenced by inflation.

\section{Conclusion}

This paper is motivated by the fact that although Ghana's financial sector was liberalized in the early 1990 s to allow for market determination of interest rates, concerns about high interest rate spreads have persisted and attracted a lot of debate in both public and policy forums. This study empirically sought to investigate the effect of interest rate spread and macroeconomic factors on banks profitability in Ghana using average annual observation data from the period of 1992-2015 and covers 28 commercial banks. Specifically, the study analyzed those factors that affect interest rate spread by applying econometric analysis to estimate the model. Ordinary Least square method were used to estimate the regression coefficients. The empirical results show that bank-specific factors play a significant role in the determination of interest rate spreads in Ghana's banking sector. All the bank specific variables were found to be significant except bank total assets (TA) to GDP.

The macroeconomic variable, inflation showed significant result inferring that inflation has a profound effect on interest rate spread. GDP growth rate was found to be insignificant. General economic activity has a strong inverted association with interest rate spreads. In periods of economic improvement, banks tend to diminish the interest rate spreads, and in time of economic deterioration, the opposite development is expected. Insignificant GDP growth rate implies that economic improvement or deterioration will not stimulate interest rate spread to impact on banks profitability. The paper has extended and strengthened some earlier results on interest rate spread changes on bank profitability in Ghana. Three innovations of the current study are the use of a comprehensive data sources, the consideration of a longer period of time covering two and half decades (1992-2015) and the incorporation of the macroeconomic variables, inflation and GDP growth rate. Obviously, the purpose is to provide a reliable background for an accurate implementation of the interest rate spread effect in determining bank profitability. High interest rates deter people from borrowing from the banks. The results of the model reveal that bank specific variables have an impact on banks interest rate spread. This suggested that banks interest rate changes have effect on banks profitability. The findings of the paper is consistent with the results obtained by Tarus et al. (2012); Were and Wambua (2014) and Njeri et al. (2015) and Mihailov (2014) who found Interest rate spread in Kenyan and Bulgeria to be influenced by return on assets, net interest income, operational cost and inflation. Despite the phenomenal growth in the financial sector, interest rates are still too high for the average Ghanaian worker and a great majority of Ghanaians are unbanked.

The role of the global financial institutions is changing and so are the banks operating in Ghana. The banking sector should explore ways in which they can take advantage of the government's policy of making the "private sector the engine of growth" to market their products. Further, there should be unwavering commitment to domestic resources mobilization. Knowledge of the interest rate changes is of particular importance to academics and policy makers as well as practitioners. Academics and policy makers seem to accept the view that financial intermediaries play a crucial role in the effective functioning of modern economies, owing to their comparative advantage in terms of information gathering, screening, and monitoring, which result in economies of scale and scope. In the increasingly fluid banking markets in Ghana, it is even more crucial for researchers, policymakers, and managers of banking providers to understand the interest rate spread and their impact on banks profitability.

\section{References}

Aboagye, A. Q., Akoena, S., Antwi-Asare, T., \& Gockel, A. (2008). Explaining interest rate spreads in Ghana. African Development Review, $20(3)$, 378-399.

Ahokpossi, M. C. (2013). Determinants of bank interest margins in Sub-Saharan Africa: International Monetary Fund.

Amuakwa-Mensah, F., \& Marbuah, G. (2015). The determinants of net interest margin in the Ghanaian banking industry. Journal of African Business, $16(3), 272-288$.

Asamoah, L. A., \& Adu, G. (2016). An empirical analysis of the determinants of interest rates in Ghana. Journal of African Business, $17(3)$, 377-396.

Bank of Ghana. (2004). Cost of banking in Ghana. An empirical assessment and implication (Policy Brief). Accra, Ghana: Bank of Ghana, Research Department. 
Bank of Ghana. (2007). Financial stability report (Vol. 7). Accra, Ghana: Author.

Bank of Ghana. (2011). Annual Report. Accra, Ghana.

Bawumia, M., Belnye, F., \& Ofori, M. E. (2005). The determination of bank interest spreads in Ghana: An empirical analysis of panel data. Working Paper, Monetary Policy Committee, Bank of Ghana.

Bokhari, J. (2004). The growing appetite of universal banking. Retrieved from http:// DAWN.Com.

Chirwa, E. W., \& Mlachila, M. (2004). Financial reforms and interest rate spreads in the commercial banking system in Malawi. IMF Staff Papers, 51(1), 96-122.

Claessens, S., \& Laevan, L. (2004). What drives bank competition? Some international evidence. Journal of Money, Credit and Banking, 36(2), 563-584.

Crowley, J. (2007). Interest rate spreads in English-speaking African countries. IMF Working Paper 07/101 (Washington: International Monetary Fund).

Demirguc-Kunt, A., \& Huizinga, H. (1999). Determinants of commercial bank interest margins and profitability: Some international evidence world bank. Economic Review, 13(2), 379-408.

Eita, J. H. (2012). Explaining interest rate spread in Namibia. International Business छ Economics Research Journal, 11(10), $1123-1132$.

Folawewo, A. O., \& Tennant, D. (2008). Determinants of interest rate spread in Sub-Saharan African countries: A dynamic panel analysis. Paper presented at the 13th Annual African Econometrics Society Conference, Pretoria, Republic of South Africa.

Gambacorta, L. (2004). How banks set interest rates? National Bureau of Economic Research Working Paper 10295, Cambridge.

Garr, D. K., \& Kyereboah-Coleman, A. (2013). Macroeconomic and industry determinants of interest rate spread-empirical evidence. Developing Country Studies, 3(12), 2225-0565.

Gelos, R. G. (2006). Banking spread in Latin America. International Monetary Fund. Working Paper 06/44.

Grenade, K. H. I. (2007). Determinants of commercial banks interest rate spreads: Some empirical evidence from the eastern Caribbean currency union. Eastern Caribbean Central Bank Staff Research Paper No. WP/ 07/01.

Hinson, R. (2004). The importance of service quality in Ghana's banking sector. The Marketing Challenge, 7(3), $16-18$.

Ho, T., \& Saunders, A. (1981a). The determinants of bank interest margins: Theory and empirical evidence. Journal of Financial and Quantitative Analysis, 16(4), 581-600.

Ho, T., \& Saunders, A. (1981b). The determinants of bank interest margins: Theory and empirical evidence. Journal of Financial Economics, 9, 47-73.

Johnson, A. C., Johnson, M. B. J., \& Buse, R. C. (1987). Econometrics basic and applied. New York: Macmillan.

Kader, R., \& Leong, Y. (2009). The impact of interest rate changes on Islamic bank financing. International Review of Business Research Papers, 5(3), 189-201.

Kwakye, J. K. (2010). High interest rates in Ghana: A critical analysis. The Institute of Economic Affairs.

Maudos, J., \& de Guevara, J. F. (2004). Factors explaining the interest margin in the banking sectors of the European Union. Journal of Banking and Finance, 28(9), 2259-2281.

Mercieca, S., Schaeck, K., \& Wolfe, S. (2007). Small banks in Europe: Benefits from diversification? Journal of Banking and Finance, 31, 1975-1998

Mihailov, M. (2014). Factors affecting bank interest rate spread dynamics in Bulgaria. Bulgarian National Bank, Discussion Papers 96/2014.

Naceur, S. B. (2003). The determinants of the Tunisian banking industry profitability: Panel evidence. Paper presented at the Economic Research Forum (ERF) 10th Annual Conference, Marrakesh-Morocco.

Nampewo, D. (2013). What drives interest rate spreads in Uganda's banking sector? International Journal of Economics and Finance, 5(1), $76-85$.

Ngugi, R. (2001). An empirical analysis of interest rate spread in Kenya. AERC Research Paper 106. Nairobi: African Economic Research Consortium (AERC).

Njeri, B. K., Ombui, K., \& Kagiri, A. W. (2015). Determinants of interest rate spread of commercial banks in Kenya. International Journal of Science and Research, 4(11), 617-620.

Obuobi, S. (2012). Current trends in Ghana's banking industry. RS Insight.

Pesaran, M. H., Shin, Y., \& Smith, R. J. (2001). Bounds testing approaches to the analysis of level relationships. Journal of Applied Econometrics, $16(3)$, 289-326.

Peshev, P. (2015). Determinants of interest rate spreads in Bulgaria. Bulgarian National Bank Discussion Papers $\mathrm{DP} / 99 / 2015$

Quaden, G. (2004). Efficiency and stability in an evolving financial system. Paper presented at the National Bank of Belgium Conference on Efficiency and Stability in an Evolving Financial System, Brussels, Belgium. Retrieved from http://www.bis.org/review/r040521b.pdf.

Raharjo, P., D., Hakim, A. M., \& Maulana, T. (2014). The determinant of commercial banks' interest margin in Indonesia: An analysis of fixed effect panel regression. International Journal of Economics and Financial Issues, 4(2), 295-308.

Sarpong, D., Winful, E. C., \& Ntiamoah, J. (2011). Determinants of wide interest margins in Ghana. Panel EGLS Analysis (pp. 3).

Sarpong, D., Winful, E. C., \& Ntiamoah, J. (2013). Determinants of wide interest margins in Ghana, panel EGLS analysis. African Journal of Business Management, 7(35), 3535-3544.

Sheriff, I., \& Amoako, G. (2014). Macroeconomic determinants of interest rate spread in Ghana: Evidence from ARDL modelling approach. Journal of Finance and Bank Management, 2(2), 115-132.

Siddiqui, M. A. (2012). Towards determination of interest spread of commercial banks: Empirical evidences from Pakistan. African Journal of Business Management, 6(5), 1851-1862.

Sologoub, D. (2006). The determinants of bank interest margins and profitability: Case of Ukraine. Retrieved from www.bof.fi/bofit/seminar/bofcefo6/sologub.pdf. 
Tarus, D., Chekol, Y. B., \& Mutwol, M. (2012). Determinants of net interest margins of commercial banks in Kenya: A panel study. Procedia Economics and Finance, 2, 199-208.

Were, M., \& Wambua, J. (2014). What factors drive interest rate spread of commercial banks? Empirical evidence from Kenya. Review of Development Finance, 4(3), 73-82.

Winston, M., \& Roland, C. (2002). Market power and interest rate spread in the Caribbean. International Review of Applied Economics, 16(4), 391-405. 